\title{
Branching out at C-2 of septanosides. Synthesis of 2-deoxy-2-C-alkyl/aryl septanosides from a bromo-oxepine
}

Supriya Dey and Narayanaswamy Jayaraman*

\section{Full Research Paper}

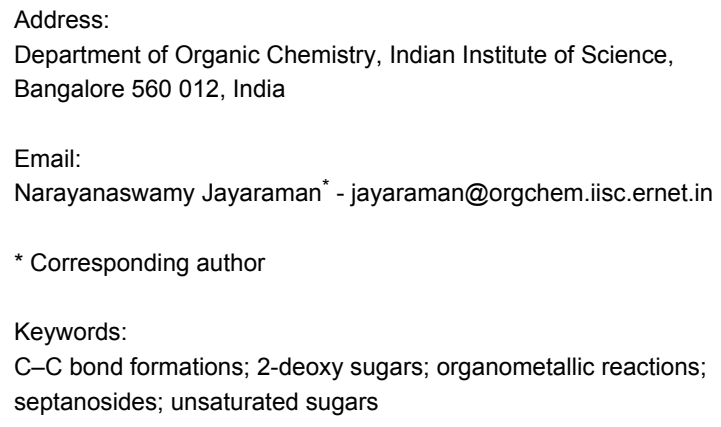

Beilstein J. Org. Chem. 2012, 8, 522-527. doi:10.3762/bjoc.8.59

Received: 21 January 2012

Accepted: 14 March 2012

Published: 10 April 2012

This article is part of the Thematic Series "Synthesis in the glycosciences II".

Guest Editor: T. K. Lindhorst

(C) 2012 Dey and Jayaraman; licensee Beilstein-Institut. License and terms: see end of document.

\begin{abstract}
This paper deals with the synthesis of 2-deoxy-2- $C$-alkyl/aryl septanosides. A range of such septanoside derivatives was synthesized by using a common bromo-oxepine intermediate, involving $\mathrm{C}-\mathrm{C}$ bond forming organometallic reactions. Unsaturated, sevenmembered septanoside vinyl bromides or bromo-oxepines, obtained through a ring expansion methodology of the cyclopropane derivatives of oxyglycals, displayed a good reactivity towards several acceptor moieties in $\mathrm{C}-\mathrm{C}$ bond forming Heck, Suzuki and Sonogashira coupling reactions, thus affording 2-deoxy-2-C-alkyl/aryl septanosides. Whereas Heck and Sonogashira coupling reactions afforded 2-deoxy-2- $C$-alkenyl and -alkynyl derivatives, respectively, the Suzuki reaction afforded 2-deoxy-2- $C$-aryl septanosides. Deprotection and reduction of the 2-deoxy-2-alkenyl derivative afforded the corresponding 2-deoxy-2- $C$-alkyl septanoside free of protecting groups. The present study illustrates the reactivity of bromo-oxepine in the synthesis of hitherto unknown septanosides, branching out at $\mathrm{C}-2$, through $\mathrm{C}-\mathrm{C}$ bond formation with alkyl and aryl substituents.
\end{abstract}

\section{Introduction}

Septanoses and septanosides are unnatural, seven-membered cyclic sugars [1]. Methods of preparation and the exploration of the properties of these unnatural sugars are of high interest [2]. An early isolation of septanose was achieved through cyclization of generic hexose sugars, which afforded minor amounts of septanose, along with furanose and pyranose, which formed in major amounts [3]. Synthetic approaches to septanoses have been explored in many instances, for example, (i) hemiacetal or acetal formation from a linear precursor containing aldehyde and an appropriately positioned hydroxyl group [4-8]; (ii) Knoevenagel-type condensation of sugar aldehyde with active methylene compounds $[9,10]$; (iii) ring-closing 
metathesis reactions of appropriately installed diene derivatives [11-13]; (iv) ring expansion of 1,2-cyclopropanated sugars [1417]; (v) Baeyer-Villiger oxidation of inositol derivatives $[18,19]$ and (vi) electrophile-induced cyclization [20]. We recently developed a new methodology to prepare septanosides, which involved a sequence of dihalocarbene insertion on to an oxyglycal, ring opening of the cyclopropyl moiety with a nucleophile, and oxidation and reduction reactions, so as to permit the expansion of six-membered pyranoses to sevenmembered septanosides [21-23]. Features of this methodology include the formation of vinyl halide, vinyl ether, diketone and diol intermediates, which are potential sites for varied types of functionalizations. While exploring such features, we undertook the preparation of septanoside derivatives that are branched out at $C$-2, so as to afford 2-deoxy-2-C-alkyl/aryl derivatives, through $\mathrm{C}-\mathrm{C}$ bond formations mediated by organometallic reagents. Details of the preparation of 2-deoxy2- $C$-aryl/alkyl septanosides are described herein.

\section{Results and Discussion}

The methodology of septanoside preparation starting from an oxyglycal is shown in Figure 1 [21]. The oxygen at $C-2$ of oxyglycal I was retained throughout until the septanoside $\mathbf{V}$ was obtained. More importantly, vinyl halide III and diketone IV also form as intermediates of the reaction and these intermediates provide an avenue to expand the scope of the reaction sequence.

In the present work, we envisaged that III would form as a synthon to implement $\mathrm{C}-\mathrm{C}$ bond forming reactions. Vinyl halide 2 was synthesized through a ring-expansion reaction of cyclopropanated adduct 1 (Scheme 1), as reported previously [21]. The reactivity at $C-2$ of $\mathbf{2}$ was examined by the chosen organometallic reactions, namely, Heck, Suzuki and Sonogashira coupling reactions. Heck coupling reactions [24,25] were undertaken first. Thus, the reaction of bromo-oxepine 2 with methyl acrylate was performed, in the presence of $\mathrm{Pd}(\mathrm{OAc})_{2}(10 \mathrm{~mol} \%)$ and $\mathrm{Cs}_{2} \mathrm{CO}_{3}$ in 1,4-dioxane, at $98{ }^{\circ} \mathrm{C}$ (Scheme 1), to afford diene 3 , in $70 \%$ yield. The presence of doublets at 7.80 and $5.97 \mathrm{ppm}(J=16.0 \mathrm{~Hz})$ in the ${ }^{1} \mathrm{H}$ NMR spectrum and signals at $136.3 \mathrm{ppm}$ and $119.5 \mathrm{ppm}$ in the ${ }^{13} \mathrm{C}$ NMR spectrum confirmed the formation of $\mathbf{3}$.

Having realized the synthesis of one product, reactions of $\mathbf{2}$ were performed with a few other substrates, namely, tert-butyl acrylate, a substrate presenting two acrylates within the molecule, styrene, and $\alpha$-methyl styrene (Scheme 1). Reactions with these substrates also afforded the diene products $4-7$, in good

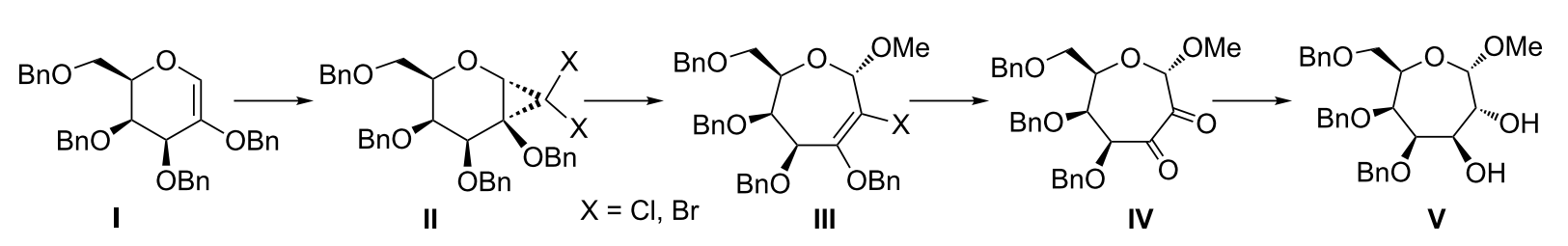

Figure 1: Synthetic route to transform oxyglycal I to a septanoside V.

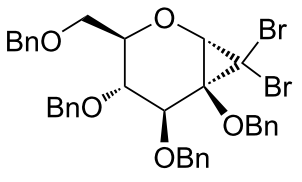

1

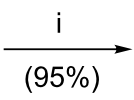<smiles>COC1OC(COc2ccccc2)[C@H](Br)[C@H](O)C(OCc2ccccc2)=C1Br</smiles>

2

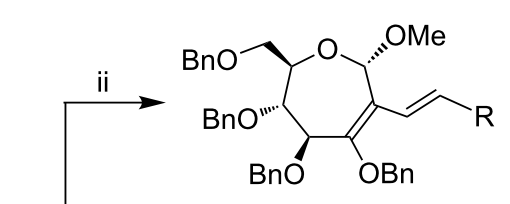

3: $\mathrm{R}=\mathrm{CO}_{2} \mathrm{Me}(70 \%)$;

4: $\mathrm{R}=\mathrm{CO}_{2} t-\mathrm{Bu}(72 \%)$

5: $\mathrm{R}=\mathrm{CO}_{2}\left(\mathrm{CH}_{2}\right)_{4} \mathrm{CH}_{2} \mathrm{OCOCH}=\mathrm{CH}_{2}(60 \%)$

6: $\mathrm{R}=\mathrm{Ph}(74 \%)$

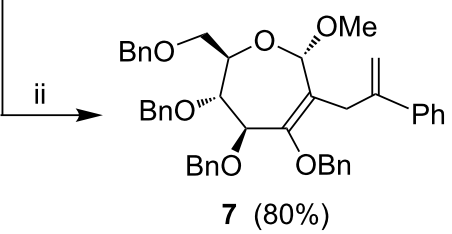


yields. The anticipated two Heck coupling reactions with the substrate that presents two acrylates, could not be achieved, rather only the mono-Heck coupling product 5 was obtained. Alternative reaction conditions were attempted, for example, by using $\mathrm{Pd}\left(\mathrm{PPh}_{3}\right)_{2} \mathrm{Cl}_{2}(10 \mathrm{~mol} \%)$, instead of $\mathrm{Pd}(\mathrm{OAc})_{2}$, while keeping other parameters of the reaction uniform, yet the double-Heck coupling product was not observed. The newly generated exocyclic olefin protons resonated as two distinct doublets in $\mathbf{4}$ at 7.72 and $5.88 \mathrm{ppm}(J=16.4 \mathrm{~Hz})$; in $\mathbf{5}$ at 7.79 and $5.93 \mathrm{ppm}(J=16.4 \mathrm{~Hz})$ and in 6 at 7.19 and $6.66 \mathrm{ppm}(J=$ $16.8 \mathrm{~Hz})$. Further, the exocyclic double-bond carbon nuclei resonated at $\sim 136-130$ and $\sim 122 \mathrm{ppm}$ in the ${ }^{13} \mathrm{C}$ NMR spectra of 4-6. The reactions afforded only the $(E)$-isomer. Interestingly, when the reaction was performed with $\alpha$-methyl styrene, product 7 , with an exocyclic double bond isomerization to a terminal double bond was observed. The appearance of two singlets at 5.30 and $5.14 \mathrm{ppm}$ in the ${ }^{1} \mathrm{H}$ NMR spectrum indicated the presence of two vinylic protons in 7 . On the other hand, the exocyclic methylene moiety at $C-2$ in 7 appeared as two distinct doublets $(3.88,3.08 \mathrm{ppm}, J=14.4 \mathrm{~Hz})$ in the ${ }^{1} \mathrm{H}$ NMR spectrum. Further structural assignments of 7 were performed through COSY and HSQC experiments.

Following the Heck coupling reactions on bromo-oxepine 2 , efforts were undertaken to implement $\mathrm{C}-\mathrm{C}$ bond forming Suzuki and Sonogashira coupling reactions. Suzuki reactions were undertaken by involving phenylboronic acid and substituted phenylboronic acids [26,27], in the presence of $\mathrm{Pd}(\mathrm{OAc})_{2}$ (10 mol \%) and $\mathrm{Cs}_{2} \mathrm{CO}_{3}$ in 1,4-dioxane at $98{ }^{\circ} \mathrm{C}$ (Scheme 2). The reactions afforded septanosides 8-10, which are derivatized with a phenyl substituent at $C-2$, in moderate yields. The formation of a $\mathrm{C}-\mathrm{C}$ bond at $C-2$ in 8-10 was inferred by the observation of shifts of the $C-2$ nuclei signal at $\sim 129 \mathrm{ppm}$, which in the case of bromo-oxepine was observed at $114.3 \mathrm{ppm}$. Analyses of ${ }^{1} \mathrm{H}$ and ${ }^{13} \mathrm{C}$ NMR spectra and mass spectra confirmed the constitution of 8-10.

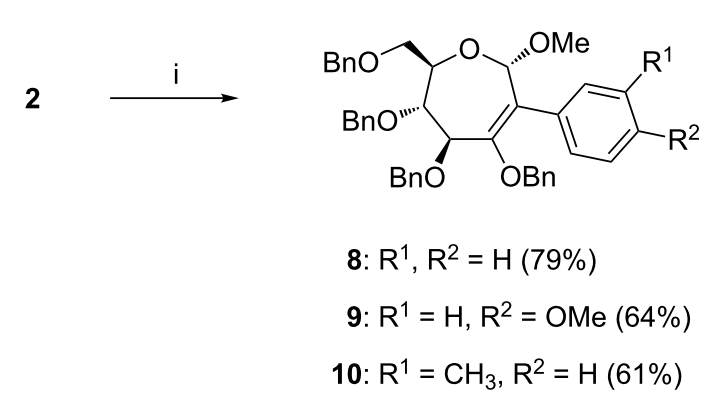

Scheme 2: Reaction conditions: (i) phenylboronic acid (for 8); 4-methoxyphenylboronic acid (for 9); 3-methylphenylboronic acid (for 10); $\mathrm{Pd}(\mathrm{OAc})_{2}(10 \mathrm{~mol} \%), \mathrm{Cs}_{2} \mathrm{CO}_{3}$ (1.5 molar equiv), 1,4-dioxane, $98^{\circ} \mathrm{C}, 72 \mathrm{~h}$.
The reactivity of bromo-oxepine, the key intermediate of the septanoside synthesis earlier, was explored further in the context of $\mathrm{C}-\mathrm{C}$ bond formation at $\mathrm{C}-2$, through another versatile $\mathrm{C}-\mathrm{C}$ bond forming reaction, namely, Sonogashira coupling [28,29]. Reactions of $\mathbf{2}$ with acetylenes were performed in the presence of $\mathrm{Pd}\left(\mathrm{PPh}_{3}\right)_{2} \mathrm{Cl}_{2}(20 \mathrm{~mol} \%)$ and $\mathrm{CuI}(10 \mathrm{~mol} \%)$ in a $\mathrm{DMF} / \mathrm{THF} / \mathrm{Et}_{3} \mathrm{~N}$ 5:3:2 solvent mixture as the optimized protocol. The use of $\mathrm{Pd}(\mathrm{OAc})_{2}$ as a catalyst or $\mathrm{Et}_{3} \mathrm{~N}$ as the base did not promote the reaction, leading only to the recovery of the starting material. Thus, the reaction of $\mathbf{2}$ with phenylacetylene and oct-1-yne led to the formation of the corresponding 2-deoxy-2-C-alkynyl septanosides 11 and 12 (Scheme 3) in moderate yields. Prolonging the reaction time and increasing the catalyst loading did not increase the yields, although dehalogenation of $\mathbf{2}$ to oxepine was found to occur to a minor extent when the reaction time was increased to several days. ${ }^{13} \mathrm{C}$ NMR spectra of 11 and 12 showed resonances for the newly formed $\mathrm{C}-\mathrm{C}$ bond at 11: $108.4 \mathrm{ppm}(C-2)$ and $95.8 \mathrm{ppm}(C \equiv \mathrm{C}-\mathrm{Ph})$; 12: $109.9 \mathrm{ppm}(C-2)$ and $97.4 \mathrm{ppm}\left(C \equiv \mathrm{C}-\mathrm{C}_{6} \mathrm{H}_{13}\right)$. Further, ${ }^{1} \mathrm{H}$ and ${ }^{13} \mathrm{C}$ NMR spectroscopic and mass spectrometric analyses confirmed the constitutions of $\mathbf{1 1}$ and $\mathbf{1 2}$.

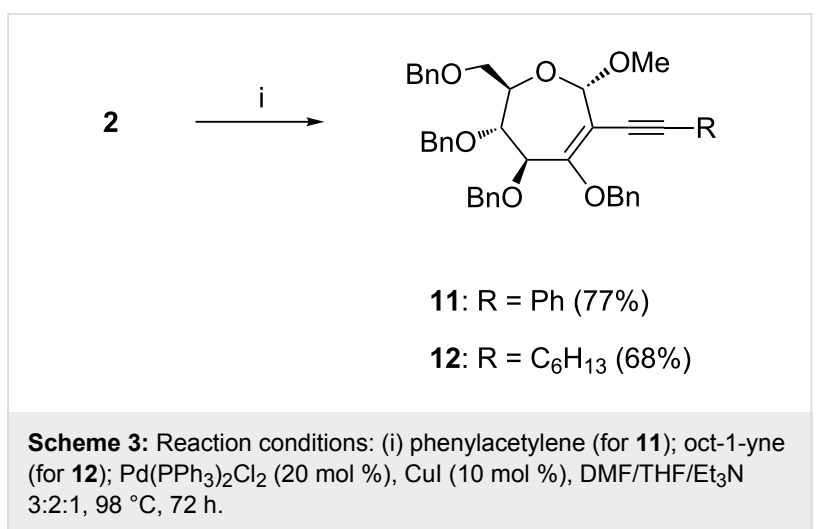

Having observed a good reactivity of bromo-oxepine 2 in $\mathrm{C}-\mathrm{C}$ bond forming reactions, we used one of the 2-deoxy-2-C-alkyl derivatives, namely, product $\mathbf{4}$ for further reactions, leading to a 2-deoxy-2- $C$-alkyl septanoside containing free hydroxyl groups. Towards this effort, 4 was subjected first to a hydrogenolysis $\left(\mathrm{Pd} / \mathrm{C}, \mathrm{H}_{2}\right)$, which afforded D-manno-sept-3-uloside 13 as single diastereomer in good yield (Scheme 4).

The configuration of C-2 in $\mathbf{1 3}$ was confirmed through HMQC and COSY experiments. A doublet at $4.37 \mathrm{ppm}$ with $J_{\mathrm{H} 1, \mathrm{H} 2}$ of $8.0 \mathrm{~Hz}$ indicated a trans-configuration of $\mathrm{H}-2$ with respect to $\mathrm{H}-1$ in 13. The presence of sets of protons in the ${ }^{1} \mathrm{H}$ NMR spectrum, one at 2.05 and $1.78 \mathrm{ppm}$ (multiplet) and the other at $2.21 \mathrm{ppm}(\mathrm{t}, J=7.4 \mathrm{~Hz}$ ), corresponding to exocyclic methylene moieties in $\mathbf{1 3}$, resulting from the concomitant reduction of the exocyclic double bond in $\mathbf{4}$, was also observed. The presence of 


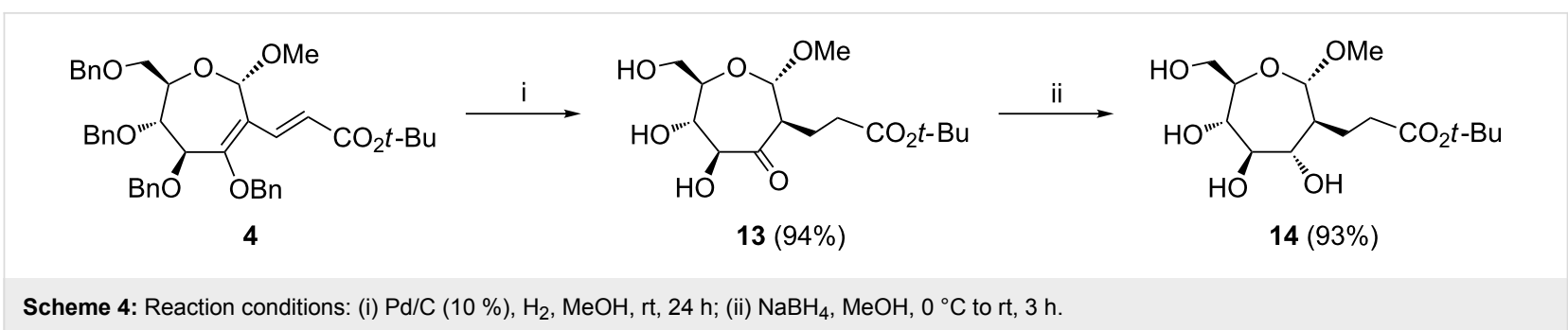

the ketone functionality in $\mathbf{1 3}$ was inferred from the resonance at $208.4 \mathrm{ppm}$ in the ${ }^{13} \mathrm{C}$ NMR spectrum. Subsequent to hydrogenolysis, the treatment of $\mathbf{1 3}$ with $\mathrm{NaBH}_{4}$ facilitated the reduction of the keto-moiety to the corresponding alcohol 14, in an excellent yield. The trans-bisequatorial configuration of the hydroxyl groups at $C-3$ and $C-4$ in $\mathbf{1 4}$ was inferred from a ${ }^{3} J_{\mathrm{H} 3, \mathrm{H} 4}$ of $12.4 \mathrm{~Hz}$, in the ${ }^{1} \mathrm{H}$ NMR spectrum. On the other hand, the proton at $C-2$ merged with the exocyclic methylene group, leading to an inability to assess the $\mathrm{H}-2, \mathrm{H}-3$ coupling constant in 14. Having defined the configuration of the substituent at $C-2$ in 13, we infer a trans-configuration of the substituent at $C-2$ and $C-3$. The results of mass spectrometric analysis concurred with the constitutions of $\mathbf{1 3}$ and $\mathbf{1 4}$.

\section{Conclusion}

The present study illustrates the effective application of synthetically useful bromo-oxepine for the preparation of hitherto unknown 2-deoxy-2-C-alkyl/aryl septanoside derivatives. C-C bond forming Heck, Suzuki and Sonogashira coupling reactions, with appropriate acrylates, arylboronic acids and alkynes, afforded the respective cross-coupled products in good yields. It is pertinent to note that the implementation of such reactions is known in seven-membered 1,2-oxazepines, so as to secure the corresponding cross-coupling products [30]. Furthermore, one of the 2-deoxy-2-C-alkyl septanoside derivatives was converted to a hydroxyl-group-free methyl 2-deoxy-2- $C$-alkyl septanoside. The present study illustrates the scope of seven-membered bromo-oxepines as useful substrates for the generation of 2-deoxy2-C-alkyl/aryl septanosides, in addition to our previous efforts to progress such intermediates to a number septanosides and septanoside-containing di- and tri-saccharides.

\section{Experimental \\ General}

Chemicals were purchased from commercial sources and were used without further purification. Solvents were dried and distilled according literature procedures. Analytical TLC was performed on commercial Merck plates coated with silica gel GF254 (0.25 mm). Silica gel (230-400 mesh) was used for column chromatography. Optical rotations were recorded on a JASCO Model P-1020 polarimeter at the sodium D line at $24{ }^{\circ} \mathrm{C}$. High-resolution mass spectra were obtained from a
Q-TOF instrument by the electrospray ionization (ESI) technique. ${ }^{1} \mathrm{H}$ and ${ }^{13} \mathrm{C}$ NMR spectral analyses were performed on $400 \mathrm{MHz}$ and $100 \mathrm{MHz}$ spectrometers, respectively, with the residual solvent signal acting as the internal standard. COSY and HSQC analyses were performed on a $400 \mathrm{MHz}$ NMR spectrometer.

Methyl 2-deoxy-2-C-(2-(tert-butoxycarbonyl)vinyl)-3,4,5,7tetra-O-benzyl-a-D-arabino-hept-2-enoseptanoside (4): A solution of 2 [21] (0.05 g, $0.07 \mathrm{mmol})$ in 1,4-dioxane (1 mL) was admixed with $\mathrm{Pd}(\mathrm{OAc})_{2}(1 \mathrm{mg}, 10 \mathrm{~mol} \%)$ under a $\mathrm{N}_{2}$ atmosphere, and this was followed by the addition of $\mathrm{Cs}_{2} \mathrm{CO}_{3}$ $(0.03 \mathrm{~g}, 0.11 \mathrm{mmol})$ and tert-butyl acrylate $(0.02 \mathrm{~mL}$, $0.153 \mathrm{mmol})$, in a sealed tube. The reaction mixture was stirred at $98^{\circ} \mathrm{C}$ for $72 \mathrm{~h}$, cooled, filtered, diluted with EtOAc $(20 \mathrm{~mL})$, washed with water $(2 \times 30 \mathrm{~mL})$ and brine $(2 \times 10 \mathrm{~mL})$, dried $\left(\mathrm{Na}_{2} \mathrm{SO}_{4}\right)$ and concentrated in vacuo. The resulting residue was purified (hexane/EtOAc 9:1) to afford $4(0.038 \mathrm{~g}, 72 \%)$, as an oil. $R_{\mathrm{f}} 0.48$ (hexane/EtOAc 9:1); $[\alpha]_{\mathrm{D}}-130.8\left(c 1.0, \mathrm{CHCl}_{3}\right)$; ${ }^{1} \mathrm{H}$ NMR (400 MHz, $\left.\mathrm{CDCl}_{3}\right) \delta 7.72(\mathrm{~d}, J=16.4 \mathrm{~Hz}, 1 \mathrm{H}$, $\left.-\mathrm{CH}=\mathrm{CHCO}_{2} t-\mathrm{Bu}\right), 7.33-7.24(\mathrm{~m}, 18 \mathrm{H}$, aromatic), 7.10-7.08 (m, $2 \mathrm{H}$, aromatic), $5.88\left(\mathrm{~d}, J=16.4 \mathrm{~Hz}, 1 \mathrm{H},-\mathrm{CH}=\mathrm{CHCO}_{2} t-\mathrm{Bu}\right)$, 5.36 (s, 1H, H-1), 4.69-4.56 (m, 4H, $\left.\mathrm{PhCH}_{2}\right), 4.48$ (d, $J=$ $\left.12.0 \mathrm{~Hz}, 1 \mathrm{H}, \mathrm{PhCH}_{2}\right), 4.43\left(\mathrm{~d}, J=12.0 \mathrm{~Hz}, 1 \mathrm{H}, \mathrm{PhCH}_{2}\right), 4.33$ (d, $\left.J=12.0 \mathrm{~Hz}, 1 \mathrm{H}, \mathrm{PhCH}_{2}\right), 4.24$ (d, $\left.J=12.0 \mathrm{~Hz}, 1 \mathrm{H}, \mathrm{PhCH}_{2}\right)$, 4.21-4.17 (m, 2H, H-4 and H-6), 3.75 (dd, $J=8.4,1.4 \mathrm{~Hz}, 1 \mathrm{H}$, H-5), 3.63-3.57 (br, 1H, H-7a), 3.53-3.52 (br, 1H, H-7b), 3.51 (s, 3H, OMe), 1.47 (s, 9H, $t$-Bu); ${ }^{13} \mathrm{C} \mathrm{NMR} \mathrm{(100} \mathrm{MHz,} \mathrm{CDCl}_{3}$ ) $\delta 166.6(\mathrm{C}=\mathrm{O}), 158.7(\mathrm{C}-3), 138.2-137.0$ (aromatic), 136.4 $\left(-\mathrm{CH}=\mathrm{CHCO}_{2} t-\mathrm{Bu}\right), 128.4-127.5$ (aromatic ), $124.4(\mathrm{C}-2)$, $121.9\left(-\mathrm{CH}=\mathrm{CHCO}_{2} t-\mathrm{Bu}\right), 100.0$ (C-1), 80.1 (C-5), 79.9 (C-4), $73.0\left(\mathrm{PhCH}_{2}\right), 72.8\left(\mathrm{PhCH}_{2}\right), 72.0\left(\mathrm{PhCH}_{2}\right), 71.2\left(\mathrm{PhCH}_{2}\right)$, 71.0 (C-6), 70.8 (C-7), 55.5 (OMe), 28.1 ( $t$-Bu); HRMS-ESI $(\mathrm{m} / z):[\mathrm{M}+\mathrm{Na}]^{+}$calcd for 715.3247 ; found, 715.3245 .

\section{Methyl 2-deoxy-2- $C$-(2-phenylallyl)-3,4,5,7-tetra- $O$-benzyl-} a-D-arabino-hept-2-enoseptanoside (7): A solution of 2 [21] $(0.05 \mathrm{~g}, 0.07 \mathrm{mmol})$ in 1,4-dioxane $(1 \mathrm{~mL})$ was admixed with $\mathrm{Pd}(\mathrm{OAc})_{2}(1 \mathrm{mg}, 10 \mathrm{~mol} \%)$ under a $\mathrm{N}_{2}$ atmosphere, and was followed by the addition of $\mathrm{Cs}_{2} \mathrm{CO}_{3}(0.03 \mathrm{~g}, 0.11 \mathrm{mmol})$ and $\alpha$-methyl styrene $(0.01 \mathrm{~mL}, 0.09 \mathrm{mmol})$ in a sealed tube. The reaction mixture was stirred at $98{ }^{\circ} \mathrm{C}$ for $72 \mathrm{~h}$, cooled, filtered, 
diluted with EtOAc $(20 \mathrm{~mL})$, washed with water $(2 \times 30 \mathrm{~mL})$ and brine $(2 \times 10 \mathrm{~mL})$, dried $\left(\mathrm{Na}_{2} \mathrm{SO}_{4}\right)$ and concentrated in vacuo. The crude reaction mixture was purified (hexane/EtOAc 92:8) to afford $7(0.042 \mathrm{~g}, 80 \%)$, as an oil. $R_{\mathrm{f}} 0.60$ (hexane/ EtOAc 9:1); $[\alpha]_{\mathrm{D}}-58.8\left(c 0.5, \mathrm{CHCl}_{3}\right) ;{ }^{1} \mathrm{H} \mathrm{NMR}(400 \mathrm{MHz}$, $\left.\mathrm{CDCl}_{3}\right) \delta 7.44(\mathrm{~d}, J=7.6 \mathrm{~Hz}, 2 \mathrm{H}$, aromatic), 7.33-7.21 (m, $21 \mathrm{H}$, aromatic), 7.18 (d, $J=4.8 \mathrm{~Hz}, 2 \mathrm{H}$, aromatic), 5.30 (app. s, $1 \mathrm{H}, \mathrm{C} H \mathrm{H}=\mathrm{CPh}), 5.14($ app. s, $1 \mathrm{H}, \mathrm{CH} H=\mathrm{CPh}), 4.98(\mathrm{~s}, 1 \mathrm{H}$, $\mathrm{H}-1), 4.58$ (d, $\left.J=12.4 \mathrm{~Hz}, 2 \mathrm{H}, \mathrm{PhCH}_{2}\right), 4.44$ (d, $J=12.0 \mathrm{~Hz}$, $\left.2 \mathrm{H}, \mathrm{PhCH}_{2}\right), 4.31\left(\mathrm{~d}, J=10.8 \mathrm{~Hz}, 2 \mathrm{H}, \mathrm{PhCH}_{2}\right), 4.22(\mathrm{~d}, J=$ $11.6 \mathrm{~Hz}, 1 \mathrm{H}, \mathrm{PhCH}_{2}$ ), 4.08-4.03 (band, 3H, H-4, H-6 and $\left.\mathrm{PhCH}_{2}\right), 3.88\left(\mathrm{~d}, J=14.4 \mathrm{~Hz}, 1 \mathrm{H},-\mathrm{CH} \mathrm{H}(\mathrm{Ph})=\mathrm{CH}_{2}\right), 3.61(\mathrm{dd}$, $J=9.2,1.6 \mathrm{~Hz}, 1 \mathrm{H}, \mathrm{H}-5), 3.55$ (dd, $J=10.4,6.4 \mathrm{~Hz}, 1 \mathrm{H}, \mathrm{H}-7 \mathrm{a})$, 3.49 (dd, $J=8.8,2.0 \mathrm{~Hz}, 1 \mathrm{H}, \mathrm{H}-7 \mathrm{~b}$ ), 3.36 (s, 3H, OMe), 3.08 $\left(\mathrm{d}, J=14.4 \mathrm{~Hz}, 1 \mathrm{H},-\mathrm{CH} H \mathrm{C}(\mathrm{Ph})=\mathrm{CH}_{2}\right) ;{ }^{13} \mathrm{C} \mathrm{NMR}(100 \mathrm{MHz}$, $\left.\mathrm{CDCl}_{3}\right) \delta 150.9(\mathrm{C}-3), 146.3\left(\mathrm{CH}_{2}-\mathrm{C}(\mathrm{Ph})=\mathrm{CH}_{2}\right), 141.0-137.3$ (aromatic), 128.3-126.6 (aromatic), 126.5 (C-2), 114.1 (C-10), 101.0 (C-1), 80.8 (C-5), $76.3(\mathrm{C}-4), 72.9\left(\mathrm{PhCH}_{2}\right), 72.0$ $\left(\mathrm{PhCH}_{2}\right), 71.7\left(\mathrm{PhCH}_{2}\right), 71.3\left(\mathrm{PhCH}_{2}\right), 71.2(\mathrm{C}-7), 70.0$ (C-6), $55.7(\mathrm{OMe}) 33.2\left(-\mathrm{CH}_{2}-\mathrm{C}(\mathrm{Ph})=\mathrm{CH}_{2}\right)$; HRMS-ESI $(\mathrm{m} / \mathrm{z})$ : $[\mathrm{M}+$ $\mathrm{Na}]^{+}$calcd for 705.3192 ; found, 705.3193.

Methyl 2-deoxy-2- $C$-( $p$-methoxyphenyl)-3,4,5,7-tetra- $O$ benzyl- $\alpha$-D-arabino-hept-2-enoseptanoside (9): A solution of 2 [21] (0.05 g, $0.07 \mathrm{mmol})$ in 1,4-dioxane $(1 \mathrm{~mL})$ was admixed with $\mathrm{Pd}(\mathrm{OAc})_{2}(1 \mathrm{mg}, 10 \mathrm{~mol} \%)$ under a $\mathrm{N}_{2}$ atmosphere, and was followed by the addition of $\mathrm{Cs}_{2} \mathrm{CO}_{3}(0.03 \mathrm{~g}, 0.11 \mathrm{mmol})$ and 4-methoxyphenylboronic acid $(0.012 \mathrm{~g}, 0.07 \mathrm{mmol})$, in a sealed tube. The reaction mixture was stirred at $98{ }^{\circ} \mathrm{C}$ for $72 \mathrm{~h}$, cooled, filtered, diluted with EtOAc $(20 \mathrm{~mL})$, washed with water $(2 \times 30 \mathrm{~mL})$ and brine $(2 \times 10 \mathrm{~mL})$, dried $\left(\mathrm{Na}_{2} \mathrm{SO}_{4}\right)$ and concentrated in vacuo. The crude reaction mixture was purified (hexane/EtOAc 8:2) to afford $9(0.033 \mathrm{~g}, 64 \%)$, as an oil. $R_{\mathrm{f}} 0.60$ (hexane/EtOAc $8: 2$ ); $[\alpha]_{\mathrm{D}}-9.8\left(c 0.1, \mathrm{CHCl}_{3}\right.$ ); ${ }^{1} \mathrm{H}$ NMR (400 MHz, $\left.\mathrm{CDCl}_{3}\right) \delta 7.38-7.11$ (m, 20H, aromatic), $6.88(\mathrm{~d}, J=7.6 \mathrm{~Hz}, 2 \mathrm{H}$, aromatic), $6.83(\mathrm{~d}, J=8.8 \mathrm{~Hz}, 2 \mathrm{H}$, aromatic), 5.37 (s, $1 \mathrm{H}, \mathrm{H}-1), 4.81$ (d, $J=12.4 \mathrm{~Hz}, 1 \mathrm{H}, \mathrm{PhCH}_{2}$ ), 4.64-4.49 (m, 3H, $\mathrm{PhCH}_{2}$ ), 4.40 (d, $J=11.6 \mathrm{~Hz}, 2 \mathrm{H}, \mathrm{PhCH}_{2}$ ), 4.32-4.29 (br, 1H, H-6), 4.28 (app. d, $J=11.2 \mathrm{~Hz}, 1 \mathrm{H}, \mathrm{H}-4$ ), 4.23 (s, $\left.2 \mathrm{H}, \mathrm{PhCH}_{2}\right), 3.80$ (s, 3H, OMe), 3.77-3.74 (br, $1 \mathrm{H}$, H-5), 3.66 (dd, $J=10.6,6.4 \mathrm{~Hz}, 1 \mathrm{H}, \mathrm{H}-7 \mathrm{a}), 3.58$ (dd, $J=10.6$, $2.4 \mathrm{~Hz}, 1 \mathrm{H}, \mathrm{H}-7 \mathrm{~b}), 3.33$ (s, 3H, OMe); ${ }^{13} \mathrm{C} \mathrm{NMR}(100 \mathrm{MHz}$, $\left.\mathrm{CDCl}_{3}\right) \delta 158.4$ (aromatic), 152.3 (C-3), 138.4-137.3 (aromatic), 130.9 (aromatic), 129.0 (C-2), 128.4-127.4 (aromatic), 113.1 (aromatic), 102.2 (C-1), 80.7 (C-5), 78.3 (C-4), $73.0\left(\mathrm{PhCH}_{2}\right), 72.6\left(\mathrm{PhCH}_{2}\right), 72.0\left(\mathrm{PhCH}_{2}\right), 71.2(\mathrm{C}-6)$, 71.1 (C-7), 55.9 (OMe), $55.2\left(-\mathrm{C}_{6} \mathrm{H}_{4} \mathrm{OMe}\right)$; HRMS-ESI $(\mathrm{m} / \mathrm{z})$ : $[\mathrm{M}+\mathrm{Na}]^{+}$calcd for 695.2985 ; found, 695.2983.

Methyl 2-deoxy-2- $C$-(octyn-1-yl)-3,4,5,7-tetra- $O$-benzyl- $\alpha$-Darabino-hept-2-enoseptanoside (12): A solution of 2 [21]

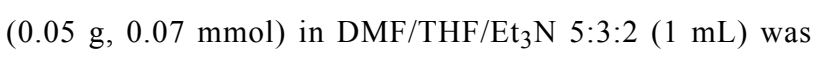
admixed with $\mathrm{Pd}\left(\mathrm{PPh}_{3}\right)_{2} \mathrm{Cl}_{2}(0.01 \mathrm{~g}, 20 \mathrm{~mol} \%)$ under a $\mathrm{N}_{2}$ atmosphere, and was followed by the addition of $\mathrm{CuI}(0.012 \mathrm{~g}$, $10 \mathrm{~mol} \%)$ and 1 -octyne $(0.023 \mathrm{~mL}, 0.14 \mathrm{mmol})$, in a sealed tube. The reaction mixture was stirred at $98{ }^{\circ} \mathrm{C}$ for $72 \mathrm{~h}$, cooled, filtered, diluted with EtOAc $(20 \mathrm{~mL})$, washed with water $(2 \times 30 \mathrm{~mL})$ and brine $(2 \times 10 \mathrm{~mL})$, dried $\left(\mathrm{Na}_{2} \mathrm{SO}_{4}\right)$ and concentrated in vacuo. The crude reaction mixture was purified (hexane/EtOAc 9:1) to afford 12 (0.035 g, 68\%), as an oil. $R_{\mathrm{f}} 0.30$ (hexane/EtOAc 9:1); $[\alpha]_{\mathrm{D}}+4.56(c 0.1$, $\left.\mathrm{CHCl}_{3}\right) ;{ }^{1} \mathrm{H}$ NMR $\left(400 \mathrm{MHz}, \mathrm{CDCl}_{3}\right) \delta 7.36-7.21(\mathrm{~m}, 18 \mathrm{H}$, aromatic), 7.07-7.05 (m, 2H, aromatic), $5.25(\mathrm{~s}, 1 \mathrm{H}, \mathrm{H}-1), 5.08$ $\left(\mathrm{d}, J=11.6 \mathrm{~Hz}, 1 \mathrm{H}, \mathrm{PhCH}_{2}\right), 4.80\left(\mathrm{~d}, J=11.6 \mathrm{~Hz}, 1 \mathrm{H}, \mathrm{PhCH}_{2}\right)$, $4.72\left(\mathrm{~d}, J=12.4 \mathrm{~Hz}, 1 \mathrm{H}, \mathrm{PhCH}_{2}\right), 4.60$ (d, $J=12.4 \mathrm{~Hz}, 1 \mathrm{H}$, $\left.\mathrm{PhCH}_{2}\right), 4.45\left(\mathrm{~d}, J=12.4 \mathrm{~Hz}, 2 \mathrm{H}, \mathrm{PhCH}_{2}\right), 4.32$ (d, $J=$ $\left.11.6 \mathrm{~Hz}, 1 \mathrm{H}, \mathrm{PhCH}_{2}\right), 4.17$ (d, $J=11.6 \mathrm{~Hz}, 1 \mathrm{H}, \mathrm{PhCH}_{2}$ ), 4.14-4.10 (band, 2H, H-4 and H-6), 3.68 (dd, $J=8.8,2.0 \mathrm{~Hz}$, $1 \mathrm{H}, \mathrm{H}-5), 3.60$ (dd, $J=6.0,3.0 \mathrm{~Hz}, 1 \mathrm{H}, \mathrm{H}-7 \mathrm{a}), 3.52-3.49$ (br, $1 \mathrm{H}, \mathrm{H}-7 \mathrm{~b}), 3.48$ (s, 3H, OMe), 2.37 (t, $J=7.2 \mathrm{~Hz}, 2 \mathrm{H}$, $\left.-\mathrm{C} \equiv \mathrm{CCH}_{2}-\right), 1.55-1.51\left(\mathrm{~m}, 1 \mathrm{H},-\mathrm{C} \equiv \mathrm{CCH}_{2} \mathrm{CH}_{2}-\right), 1.42-1.35(\mathrm{~m}$, $\left.1 \mathrm{H},-\mathrm{C} \equiv \mathrm{CCH}_{2} \mathrm{CH}_{2}-\right), 1.30-1.18\left(\mathrm{~m}, 6 \mathrm{H},-\mathrm{C} \equiv \mathrm{C}\left(\mathrm{CH}_{2}\right)_{2}\left(\mathrm{CH}_{2}\right)_{3}-\right)$, $0.86\left(\mathrm{t}, J=6.8 \mathrm{~Hz}, 3 \mathrm{H},-\mathrm{C} \equiv \mathrm{C}\left(\mathrm{CH}_{2}\right)_{5} \mathrm{CH}_{3}\right) ;{ }^{13} \mathrm{C} \mathrm{NMR}$ $\left(100 \mathrm{MHz}, \mathrm{CDCl}_{3}\right) \delta 160.9$ (C-3), 138.4-137.5 (aromatic), 128.4-127.4 (aromatic), 109.9 (C-2), 100.8 (C-1), 97.4 (- $\left.\mathrm{C} \equiv \mathrm{CCH}_{2} \mathrm{CH}_{2}-\right), 80.4$ (C-5), 78.6 (C-4), 75.7 (-C $\left.\equiv \mathrm{CCH}_{2} \mathrm{CH}_{2}{ }^{-}\right)$, $73.3\left(\mathrm{PhCH}_{2}\right), 72.8\left(\mathrm{PhCH}_{2}\right), 71.8\left(\mathrm{PhCH}_{2}\right), 71.2\left(\mathrm{PhCH}_{2}\right)$, 71.1 (C-6), 70.8 (C-7), 55.9 (OMe), $31.3\left(-\mathrm{C} \equiv \mathrm{C}\left(\mathrm{CH}_{2}\right)_{3} \mathrm{CH}_{2}-\right)$, $28.6\left(-\mathrm{C} \equiv \mathrm{C}\left(\mathrm{CH}_{2}\right)_{4} \mathrm{CH}_{2}-\right), 28.5\left(-\mathrm{C} \equiv \mathrm{CCH}_{2} \mathrm{CH}_{2}-\right), 22.5$ $\left(-\mathrm{C} \equiv \mathrm{C}\left(\mathrm{CH}_{2}\right)_{2} \mathrm{CH}_{2}-\right), 20.0 \quad\left(-\mathrm{C} \equiv \mathrm{CCH}_{2}\left(\mathrm{CH}_{2}\right)_{4} \mathrm{CH}_{3}\right), 14.3$ $\left(-\mathrm{C} \equiv \mathrm{C}\left(\mathrm{CH}_{2}\right)_{5} \mathrm{CH}_{3}\right)$; HRMS-ESI $(\mathrm{m} / \mathrm{z}):[\mathrm{M}+\mathrm{Na}]^{+}$calcd for 697.3505; found, 697.3507.

Methyl 2-deoxy-2-C-(2-(tert-butoxycarbonyl)ethyl)- $\alpha$-Dmanno-sept-3-uloside (13): A mixture of 4 (0.038 g, $0.054 \mathrm{mmol})$ and $\mathrm{Pd} / \mathrm{C}(10 \%, 0.030 \mathrm{~g})$ in $\mathrm{MeOH}(10 \mathrm{~mL})$ was stirred under a positive pressure of $\mathrm{H}_{2}$ for $24 \mathrm{~h}$ at rt, filtered through a celite pad, and washed with $\mathrm{MeOH}(2 \times 15 \mathrm{~mL})$, and the solvents were removed in vacuo to afford $13(0.017 \mathrm{~g}$, $94 \%)$, as an oil. $R_{\mathrm{f}} 0.3\left(\mathrm{MeOH} / \mathrm{CHCl}_{3} 1: 1\right) ;[\alpha]_{\mathrm{D}}+63.12(c 0.5$, $\mathrm{MeOH}) ;{ }^{1} \mathrm{H}$ NMR (400 MHz, CD $\left.3 \mathrm{OD}\right) \delta 4.37(\mathrm{~d}, J=8.0 \mathrm{~Hz}$, $1 \mathrm{H}, \mathrm{H}-1$ ), 4.28 (app. d, $J=7.6 \mathrm{~Hz}, 1 \mathrm{H}, \mathrm{H}-4$ ), 4.08 (m, 1H, H-6), 3.85 (dd, $J=13.6,2.4 \mathrm{~Hz}, 1 \mathrm{H}, \mathrm{H}-7 \mathrm{a}), 3.73$ (dd, $J=13.6,4.8$ $\mathrm{Hz}, 1 \mathrm{H}, \mathrm{H}-7 \mathrm{~b}), 3.46$ (s, 3H, OMe), 3.35 (br, 1H, H-5), $3.22-3.17(\mathrm{~m}, 1 \mathrm{H}, \mathrm{H}-2), 2.21\left(\mathrm{t}, J=7.4 \mathrm{~Hz}, 2 \mathrm{H},-\mathrm{CH}_{2-}\right.$ $\left.\mathrm{CH}_{2} \mathrm{CO}_{2} t-\mathrm{Bu}\right), 2.10-2.01\left(\mathrm{~m}, 1 \mathrm{H},-\mathrm{CHHCH}_{2} \mathrm{CO}_{2} t-\mathrm{Bu}\right)$, 1.83-1.75 (m, $\left.1 \mathrm{H},-\mathrm{CH} H \mathrm{CH}_{2} \mathrm{CO}_{2} t-\mathrm{Bu}\right), 1.49$ (s, 9H, $\left.t-\mathrm{Bu}\right)$; ${ }^{13} \mathrm{C}$ NMR (100 MHz, CD 3 OD) $\delta 208.4(\mathrm{C}-3), 175.3(\mathrm{C}=\mathrm{O})$, 103.4 (C-1), 84.5 (C-4), 83.1 (C-t-Bu), 73.2 (C-5), 71.0 (C-6), 62.7 (C-7), 56.6 (OMe), $52.2(\mathrm{C}-2), 33.9\left(-\mathrm{CH}_{2} \mathrm{CH}_{2} \mathrm{CO}_{2} t-\mathrm{Bu}\right)$, $28.2(t-\mathrm{Bu}), 23.3\left(-\mathrm{CH}_{2} \mathrm{CH}_{2} \mathrm{CO}_{2} t-\mathrm{Bu}\right)$; HRMS-ESI $(\mathrm{m} / \mathrm{z})$ : $[\mathrm{M}+$ $\mathrm{Na}]^{+}$calcd for 357.1525 ; found, 357.1526 . 


\section{Supporting Information}

\section{Supporting Information File 1}

Experimental procedures and spectroscopic data. [http://www.beilstein-journals.org/bjoc/content/ supplementary/1860-5397-8-59-S1.pdf]

\section{Acknowledgements}

We thank the Department of Science and Technology, New Delhi, for a financial support. SD thanks Council of Scientific and Industrial Research, New Delhi, for a senior research fellowship.

\section{References}

1. Collins, P. M.; Ferrier, R. J. Monosaccharides: Their Chemistry and Their Roles in Natural Products. John Wiley \& Sons: Chichester, UK, 1998; pp 40-42.

2. Pakulski, Z. Pol. J. Chem. 2006, 80, 1293-1326.

3. Stevens, J. D. J. Chem. Soc. D 1969, 1140-1141. doi:10.1039/C29690001140

4. Stevens, J. D. Carbohydr. Res. 1972, 21, 490-492. doi:10.1016/S0008-6215(00)84936-8

5. Anet, E. F. L. J. Carbohydr. Res. 1968, 8, 164-174. doi:10.1016/S0008-6215(00)80152-4

6. Contour, M.-O.; Fayet, C.; Gelas, J. Carbohydr. Res. 1990, 201, 150-152. doi:10.1016/0008-6215(90)84232-J

7. Tauss, A.; Steiner, A. J.; Stütz, A. E.; Tarling, C. A.; Withers, S. G.; Wrodnigg, T. M. Tetrahedron: Asymmetry 2006, 17, 234-239. doi:10.1016/j.tetasy.2005.12.007

8. Sizun, G.; Dukhan, D.; Griffon, J.-F.; Griffe, L.; Meillon, J.-C.; Leroy, F.; Storer, R.; Sommadossi, J.-P.; Gosselin, G. Carbohydr. Res. 2009, 344, 448-453. doi:10.1016/j.carres.2008.12.019

9. Butcher, M. E.; Ireson, J. C.; Lee, J. B.; Tyler, M. J. Tetrahedron 1977, 33, 1501-1507. doi:10.1016/0040-4020(77)88012-5

10. Ovaa, H.; Leeuwenburgh, M. A.; Overkleeft, H. S.; van der Marel, G. A.; van Boom, J. H. Tetrahedron Lett. 1998, 39, 3025-3028. doi:10.1016/S0040-4039(98)00324-4

11. Peczuh, M. W.; Snyder, N. L. Tetrahedron Lett. 2003, 44, 4057-4061. doi:10.1016/S0040-4039(03)00849-9

12. Schmidt, B.; Biernat, A. Chem.-Eur. J. 2008, 14, 6135-6141. doi:10.1002/chem.200800567

13. Alcázar, E.; Pletcher, J. M.; McDonald, F. E. Org. Lett. 2004, 6, 3877-3880. doi:10.1021/ol0483495

14. Hoberg, J. O.; Bozell, J. J. Tetrahedron Lett. 1995, 36, 6831-6834. doi:10.1016/0040-4039(95)01387-W

15. Cousins, G. S.; Hoberg, J. O. Chem. Soc. Rev. 2000, 29, 165-174 doi:10.1039/a906932a

16. Ramana, C. V.; Murali, R.; Nagarajan, M. J. Org. Chem. 1997, 62, 7694-7703. doi:10.1021/jo970948k

17. Hewitt, R. J.; Harvey, J. E. J. Org. Chem. 2010, 75, 955-958. doi:10.1021/jo902306a

18. Fukami, H.; Koh, H.-S.; Sakata, T.; Nakajima, M. Tetrahedron Lett. 1968, 9, 1701-1704. doi:10.1016/S0040-4039(01)99032-X

19. Wang, Z.-X.; Miller, S. M.; Anderson, O. P.; Shi, Y. J. Org. Chem. 1999 64, 6443-6458. doi:10.1021/jo9908849
20. Köver, A.; Matheu, M. I.; Díaz, Y.; Castillón, S. ARKIVOC 2007, part (iv), 364-379.

21. Ganesh, N. V.; Jayaraman, N. J. Org. Chem. 2007, 72, 5500-5504. doi:10.1021/jo070444e

22. Ganesh, N. V.; Jayaraman, N. J. Org. Chem. 2009, 74, 739-746. doi:10.1021/jo801967s

23. Ganesh, N. V.; Raghothama, S.; Sonti, R.; Jayaraman, N. J. Org. Chem. 2010, 75, 215-218. doi:10.1021/jo901945e

24. Heck, R. F.; Nolley, J. P. J. Org. Chem. 1972, 37, 2320-2322. doi:10.1021/jo00979a024

25. de Meijere, A.; Meyer, F. E. Angew. Chem. 1994, 106, 2473-2506. doi:10.1002/ange.19941062307

26. Miyaura, N.; Yamada, K.; Suzuki, A. Tetrahedron Lett. 1979, 20 , 3437-3440. doi:10.1016/S0040-4039(01)95429-2

27. Miyaura, N.; Suzuki, A. Chem. Rev. 1995, 95, 2457-2483. doi:10.1021/cr00039a007

28. Sonogashira, K.; Tohda, Y.; Hagihara, N. Tetrahedron Lett. 1975, 16 , 4467-4470. doi:10.1016/S0040-4039(00)91094-3

29. Chinchilla, R.; Nájera, C. Chem. Soc. Rev. 2011, 40, 5084-5121. doi:10.1039/c1cs15071e

30. Al-Harrasi, A.; Fischer, S.; Zimmer, R.; Reissig, H.-U. Synthesis 2010, 304-314. doi:10.1055/s-0029-1217126

\section{License and Terms}

This is an Open Access article under the terms of the Creative Commons Attribution License (http://creativecommons.org/licenses/by/2.0), which permits unrestricted use, distribution, and reproduction in any medium, provided the original work is properly cited.

The license is subject to the Beilstein Journal of Organic Chemistry terms and conditions:

(http://www.beilstein-journals.org/bjoc)

The definitive version of this article is the electronic one which can be found at: doi:10.3762/bjoc. 8.59 